$1984-33642$

NASA Technical Memorandum 83789

\title{
Photovoltaic Power System for Satellite Earth Stations in Remote Areas: Project Status and Design Description
}

Richard DeLombard

Lewis. Research Center

Cleveland, Ohio

Prepared for the

International Telecommunications Energy Conference

sponsored by the Communications Society of the Institute of Electrical and Electronics Engineers

New Orleans, Louisiana, November 4-7, 1984 
PHOTOVOLTAIC POWER SYSTEM FOR SATELLITE EARTH STATIONS IN REMOTE AREAS: PROJECT STATUS AND DESIGN DESCRIPTION

\author{
Richard DeLombard \\ National Aeronautics and Space Administration \\ Lewis Research Center \\ Cleveland, Ohio 44135
}

\title{
SUMMARY
}

A photovoltaic power system will be installed at a remote location in Indonesia to provide power for a satellite earth station and a classroom for video and audio teleconferences. The earth station may also provide telephone service to a nearby village. This activity is being implemented in support of the Agency for International Development's Rural Satelilte Program. The purpose of this program is to demonstrate the use of satellite communications for development assistance applications. The purpose of the photiovoltaic power system project is to demonstrate the sultability of a hybrid photovoltaic engine-generator power system for remote satellite earth stations. This paper discusses the Indonesian Rural Satellite Project and describes the photovoltaic power system.

\section{INTRODUCTION}

The NASA Lewis Research Center (LeRC) manages two projects involving the development and field testing of small-scale, decentralized stand-alone photovoltaic (PV) power systems. These projects were initiated in response to congresstional mandates in the mid to late $170 \mathrm{~s}$. For the U.S. Department of Energy, LeRC manages the PV Stand-Alone Applications Project which is part of the National PV Program. The objective of this project is to expand the PV stand-alone application technology base in support of U.S. industry. For the U.S. Agency for International Development (AID), LeRC manages the PV Technology Project, the objective of which is to determine the suitability (1.e. reliability and cost-competitiveness) of PV power systems for development assistance activities in rural areas of developing countries.

These projects support the development of stand-alone PV technology in that they provide needed systems experience in a real-world setting. Furthermore, they serve to stimulate interest in and an awareness of PV systems on the part of planners and decision makers from Third World countries and within the international development assistance community.

AID requested that LeRC examine the use of PV stand-alone systems for remote earth station applications within the context of the AID-funded Rural Satellite Program (RSP). The Academy for Educational Development (AED), Washington, D.C. manages the RSP for AID. Teleconsult, a subcontractor, provides technical consulting services. The RSP is intended to demonstrate that satellite communications can be used to provide reliable and cost-effective communication service to rural areas throughout the developing world. A cooperative effort between the United States and host country governments, the RSP supports such basic aspects of development as health care, agriculture improvement, adult literacy and classroom education (ref. 1). 
As part of the RSP in Indonesia, a low-power satelitte communications earth station powered by a PV power system will be field tested at a remote location on the island of Sulawesi. The project, illustrated conceptualiy in figure 1, will establish a communications link between several main college campuses and a remote classroom via satellite communications.

This paper reviews the status of both the RSP in Indonesia and the PV power system development and includes a description of the PV power system.

\section{BACKGROUND}

The Indonesian Rural Satellite Project, jointly planned and funded by the Indonesian government and AID, includes technical assistance and training with emphasis on improved agricultural education.

An audio teleconferencing system, linked by Indonesia's PALAPA satellite system, provides a satellite conferencing link for 11 main campus locations of the Eastern Islands University Association (BKS) and a conference room in the offices of the Directorate General of Higher Education in Jakarta (fig. 2). The 11 main classrooms and the conference room are each equipped with an audio conferencing system, a facsimile machine and an electronic blackboard. The 12 locations have the capability of being connected together for conferencing activities and distributed classroom instruction.

A remote classroom with a conferencing system will be added to the teleconference system in December 1984. The PV-powered earth station will serve as the communication link for the remote classroom. The national telecommunications authority, PERUMTEL, may also use the earth station to provide telephone service for a nearby village.

Under the PV Technology Project, the AID Office of Energy is evaluating PV technology for a variety of remote applications. While commerclal PV systems have been and are being used for certain communications applications (e.g. two-way radios, microwave repeaters). such systems have not yet been used for remote two-way earth station applications. The Indonesian RSP provided a unique opportunity to field-test a PV power system for that application category.

In 1ate 1982, AID requested that LeRC develop and field test a PV power system as part of the Indonesian RSP. Early in 1983, a Request For Proposals for a competitive contract was issued by LeRC for the design, installation and field testing of such a PV power system. In October 1983, Hughes Aircraft Company was awarded a contract to implement this activity.

In early 1984, a site for the remote classroom, earth station and the PV power system on the island of Sulawesi (fig. 2) was selected by the Indonesian RSP staff. At about the same time, the RSP staff initiated a contract for the procurement of the earth station.

\section{DESIGN CONSIDERATIONS}

There are several considerations that affect the design of a PV power system. The major considerations for this project were: available project 
funds, available solar energy (insolation) data, site location, transportability, load energy consumption, load power profile and power system output characteristics.

Practically all earth stations that transmit and receive require some means of air conditioning. For a state-of-the-art earth station for use with domestic sateliltes, the power and energy requirements for the air conditioning are often equivalent to that of the earth station itself. For the Indonesian RSP, it was necessary to minimize the datly energy required by the earth station to reduce the size of the photovoltaic array and battery. This was due primarily to budget constraints. AED, therefore, included a requirement for low operating power in the specifications for the earth station procurement. The operating power was reduced through the use of high-effictency low-power amplifiers, elimination of the air conditioner and turning off the earth station and classroom loads during nonoperating hours.

The sizes of the PV array and the battery for a stand-alone photovoltalc system are normally based on the amount of sunlight avallable (insolation) at the planned installation site, the electrical load requirements (power level and dally profile) and the avallable funds. At the time of contract award to Hughes, the precise site location was uncertain and only approximate values were known for the load use pattern and load power requirements. The size of the PV array was, therefore, based on estimates of the insolation and the approximate load pattern, as well as funding limitations. The actual daily energy output of the PV array will depend on the actual insolation characteristics of the installation site. If there is a short-term deficit in the array energy relative to the load energy, the battery will supply the requisite energy. For a long-term deficit, the engine-generator will supply the requisite energy.

Possible installation of telephone service to the nearby village will also have an effect on the dally amount of energy used. Although the PV power system does not supply energy to the village telephone system, the earth station must be in an operating mode for telephone communications. The additional earth station power for telephone communications over and above classroom communications is not great, but PERUMTEL had initially requested extended evening hours for telephone operation. Until the amount of available energy is determined, evening operating hours for telephone service would be restricted.

If full commerclal telephone service were to be installed, using the earth station, the PV power system would not be able to supply the required energy. PERUMTEL would then need to furntsh a standard ac supply.

These considerations of load power level and usage resulted in the load profile for the earth station and remote classroom given in table I. A block diagram of the PV power system for this application is shown in figure 3 .

Transportability was also a design consideration as the Indonesians wanted the option of moving the earth station from one site to another to demonstrate its suitability in different parts of the country. 


\section{SYSTEM DESCRIPTION}

\section{Load Requirements}

The load devices to be powered by the PV power system are shown schematically in figure 4 and include the earth station, an $800 \mathrm{~W}$ inverter, telephone terminal equipment, graphics equipment, facsimile machine and the audio convener. All of these load devices are supplied by the RSP. The power requirements of the varfous load devices are shown in table $I$.

The $800 \mathrm{~W}$ inverter was originally intended to power only the earth station. The $500 \mathrm{~W}$ inverter which is part of the PV power system was to power the classroom equipment. The avallable increments of inverter size from the supplier forced the choice of the $800 \mathrm{~W}$ inverter to power the $460 \mathrm{~W}$ earth station. To reduce the tare power lost in two operating inverters, it was decided that the classroom loads would also be powered from the $800 \mathrm{~W}$ inverter. The $800 \mathrm{~W}$ inverter will also allow for the future expansion of the earth station for more telephone channels.

The cooling fans for the earth station are powered by $48 v$ dc to reduce the amount of power passed through the inverter with the attendant losses. In the backup mode, when the engine-generator is furnishing power to the system, the fans operate from the fan power supply.

\section{Basic Power System Design}

General. - A cost plus fixed fee contract was awarded to Hughes on October 7, 1983 for the design, fabrication, installation and one year operational support of the PV power system. The task elements of this contract are outlined in table II.

The system design proposed by Hughes was a slight modification of that developed by Hughes under a prior LeRC contract for a modular PV system design (ref. 2). One of the objectives of the previous contract was to develop a generic PV system design suitable for nearly any location in the world. The particular requirements of the remote earth station application led to some modifications of the previous standard design. Two major modifications are the addition of the backup engine-generator and the inverter.

A simplified schematic of the PV power system and loads is shown in figure 4. The major components of the power system are the system controller, PV array, battery, inverter, battery charger and the engine-generator. The primary mode of power system operation is for the array and battery to provide dc power to the loads. The engine-generator serves as a backup power source in either of two methods. In the first method, the engine-generator and battery charger charge the batteries and power the loads concurrently. In the second method, the engine-generator powers the loads directly.

System controller. - The control algorithm used in the controller can best be described by reference to table III. Various functions are performed as the battery state-of-charge ( $S O C$ ), as measured by the system (and battery) voltage, changes. The controller has several comparators that sense the voltage levels noted in table III and initiate the appropriate actions. 
Battery SOC control is performed by temporarily and successively switching off the two array sections at high levels of SOC or turning the enginegenerator on at low levels of SOC. When the controlier senses that the battery is nearly at 100 percent SOC, it switches off the two sections of the array to reduce the battery charging current. As the voltage decreases, the array sections are switched on again. If the battery is at approximately 40 percent SOC, the controller initiates the start of the engine-generator to charge the batteries. During this method of engine-generator operation, the loads continue to receive power through the $800 \mathrm{~W}$ inverter.

The power system is designed to respond to two types of fallures, nominally termed "soft" and "hard." A "soft" fallure occurs when the array electrical energy output has not been sufficient to meet the load demands and to keep the battery charged. The battery would then become discharged. The controller would automatically start the engine-generator to charge the battery through the battery charger. The controller would stop the engine-generator when the battery reaches approximately 90 percent SOC. Since this type of fallure would be the most likely to occur, this is a no-break type of power backup.

A "hard" fallure occurs when there has been a fallure of a critical part of the power system and the system cannot supply any power to the loads. The engine-generator would then have to be manually started and used to power the loads until the PV power system could be repaired and returned to service. Since this type of fallure is less likely to occur, a break in service is tolerated for this type of power backup.

Extreme over- and under-voltage system protection is also included in the controller functions. An over-voitage condition results from overcharging the battery due to a fallure of the controller, engine-generator and/or battery charger. In this case, the controller would disconnect the PV array and engine-generator from the battery. An under-voltage condition would generally be caused by the lack of insolation over a period of time, overuse of the loads, fallure of the engine-generator to start, fallure of the battery charger or a combination of these causes. In this case, the controller would disconnect the loads from the battery.

PV array. - The output power of a PV cell is essentially directly proportional to the intensity of the incident solar energy. PV cells are electrically wired together and physically encapsulated into PV modules which are wired and grouped together into a PV array. The voltage and current add when modules are connected in series and parallel, respectively. It is thus possible to configure the array to produce the desired voltage, current and power needed for a particular application.

PV modules from Solec International. Inc.. were selected by Hughes for this project as a result of a competitive bid process. These modules are rated at $66 \mathrm{~W}\left(15.6 \mathrm{~V}\right.$ and $4.23 \mathrm{~A}$ at $\left.28^{\circ} \mathrm{C}\right)$. Four modules in series result in a nominal system voltage of $48 \mathrm{~V}$. Each $48 \mathrm{~V}$ string has a rated current and power output of $4.23 \mathrm{~A}$ and 264 peak $W\left(28^{\circ} \mathrm{C}\right)$, respectively. Hughes' power system sizing calculations resulted in a PV array size of $1584 \mathrm{~W}\left(28^{\circ} \mathrm{C}\right)$ resulting in six strings wired in parallel. The rated output power is 1404 peak $W$ at the expected operating temperature of $48^{\circ} \mathrm{C}$. 
The array structure is a simple, above-ground structure composed of foundation tubs, upright supports and cross straps. The tubs are filled with ballast material, such as rocks or earth, obtained from the installation site. The system batteries are mounted on the top of the tubs to add additional ballast weight to the structure. The prototype array constructed for the modular PV system design contract is shown in figure 5. The array structure design facilitates disassembly and transport with the array structure entirely above ground as opposed to having footers or pillars in the ground. This design meets the transportability requirements requested by the Indonesians.

Battery. - The storage battery provides an energy leveling function for the system. When more energy is produced by the array than is being used.by the loads, such as at midday on a sunny day, excess energy is stored in the battery. When less energy is produced by the array than is being used by the loads, such as on a cloudy day or at night, energy is extracted from the battery. As discussed above, the controller prevents the battery from becoming overcharged or severely discharged.

The battery is composed of 24 C\&D Power Systems, type 3KCPSA-5, three cell packs. Each three cell pack is rated at $340 \mathrm{~A}-\mathrm{hr}\left(500 \mathrm{hr}\right.$ rate) at $25^{\circ} \mathrm{C}$. The battery configuration consists of three parallel strings, each string containing eight packs in series. This results in a battery with a nominal voltage of $48 \mathrm{~V}$ and a nominal capacity of $1020 \mathrm{~A}-\mathrm{hr}$ or 49 . kWh.

$500 \mathrm{~W}$ inverter. - The inverter provides an ac output of $220 \mathrm{~V}$ at $50 \mathrm{~Hz}$; which is compatible with Indonesian commercial utility power. The output power rating is $500 \mathrm{~W}$. This inverter is used in a cold standby mode and would be operated only if the $800 \mathrm{~W}$ inverter and the engine-generator have both failed.

Battery charger. - The battery charger provides a controlled voltage and current to charge the battery from the engine-generator. As explained earlier, the engine-generator is started when the battery SOC has fallen below a certain leve1. This backup operation provides for continuous power to the load. The output capacity of the battery charger is $2.4 \mathrm{~kW}$, which is sufficient to power the loads and simultaneously charge the battery in approximately $10 \mathrm{hr}$.

Engine generator. - The engine-generator provides an ac output of $220 \mathrm{~V}$ at $50 \mathrm{~Hz}$, and is primarily used for backup power for the earth station and the classroom. The output capacity of 2.5 kVA is sufficient to power the loads and charge the battery. The engine-generator is started automatically upon command from the controller, or manually, if necessary, by an operator. Enginegenerator power is also available to power maintenance and test equipment for the earth station.

\section{Project Specific Design Features}

Transportability. - As discussed above, transportability was one of the PV power system design considerations. The array structure design and battery selection reflect this requirement.

The array structure used in the Hughes design offers several advantages. The structure is not implanted in the ground and does not require much (if any) site preparation, yet is rigid enough to properly support the PV modules. The design and construction is simple and straightforward and allows for onsite assembly by relatively unskilled personnel. 
Physical size of the batteries was a design consideration. The three cell packs of batteries each weigh 131 ibs, which is a reasonable weight from the standpoint of transporting and handling the batterles. The use of lower weight individual cells would have increased the number of pieces threefold, whereas the use of more cells per pack would have. increased the weight and size to the point of being unmanageable in the field.

Reliability. - The avallability of power has been enhanced through the incorporation of an engine-generator in the system design. No interruption in power will occur when the engine-generator is automatically started and stopped to charge the battery if the battery SOC becomes low. In the unlikely event that the PV power system is unable to provide power to the loads, the enginegenerator alone is capable of supplying the required power to all the loads.

As presently configured, the $500 \mathrm{~W}$ inverter will function in a cold standby mode. The $800 \mathrm{~W}$ inverter supplied with the earth station furnishes ac power for the earth station as well as for the classroom equipment. In the event that both the $800 \mathrm{~W}$ inverter and the engine-generator fall, the $500 \mathrm{~W}$ inverter is capable of providing power to the earth station and the audio convener. Since the inverter would be operating at maximum capacity. its use would have to be restricted to operator messages to request maintenance assistance.

\section{PROJECT:STATUS}

\section{PV Power System}

Fabrication/testing. - As of August 1984, the power system design is complete and component fabrication is proceeding. Proof-of-design testing of the PV power system is scheduled for September.

Schedule/milestones. - The schedule is shown in figure 6 with major milestones indicated for the PV power system design, testing, installation and operation. The PV power system is currently scheduled to be ready for shipmenit in late September 1984.

\section{Indonesian Rural Satellite Project}

Implementation. - There are three separate areas of activity involved in project implementation: software development, personnel training, and installation of the classroom equipment.

Four agricultural educational programs are being developed for use with the teleconferencing system. In these courses, faculty will use the interactive audio and graphics capabilities of the teleconferencing system to teach the classes.

Two five-day workshops have been held in Indonesia for over 45 faculty members who will be using the system initially. Short-term training was conducted in the United States during 1983 and 1984 for 12 faculty members from universities and teacher training institutions. The objectives of this shortterm training were to acquaint the group with the technology of the teleconferencing system, provide instruction in teleconferencing teaching techniques, 
and, perhaps most important, help to improve skilis in curriculum development. These faculty members will assist other BKS faculty in adapting their course materlals to the teleconferencing teaching mode and understanding the system's technical capabilities (ref. 3).

The classroom equipment for the 11 main campus locations and the conference room was installed in early 1984. The majority of the equipment is operating satisfactorily, however, the terrestrial telephone lines to the classrooms have been found to be noisy. PERUMTEL is working with AED in an attempt to minimize the noise problem.

Schedule/milestones. - The schedule is shown in figure 6 with major milestones indicated for the shipping, installation and operation of the earth station. The earth station will be ready for shipment by late September 1984.

\section{CONCLUDING REMARKS}

The PV power system demonstration project described herein is expected to have an impact on the future choices of power systems for remote telecommunication applications, particularly those involving earth stations. The worldwide use of earth stations in remote areas is expected to increase dramatically in the future, especially with Intelsat's new standard for small earth stations. The high reliability, low fuel cost and low maintenance features of PV-hybrid power systems make them an attractive alternative for such applications.

\section{REFERENCES}

1 UPLINK. No. 2, Pp. 1, 4 and 6, July 1982.

2 G. J. Naff and N. A. Marshal1, "Photovoltalc Stand-Alone Modular Systems Phase II-Final Report", HAC-E8179, Hughes Aircraft Co., Long Beach, CA, July 1983. (NASA-CR-168230).

3 UPLINK. No. 4, Pp. 1 and 10, February 1984.

TABLE I. - LOAD PROFILE FOR EARTH STATION AND CLASSROOM

\begin{tabular}{|l|c|c|c|c|}
\hline \multicolumn{1}{|c|}{ Load device } & $\begin{array}{c}\text { Power, } \\
\text { W }\end{array}$ & $\begin{array}{c}\text { Hours/ } \\
\text { day, } \\
\text { hr }\end{array}$ & $\begin{array}{l}\text { Days/ } \\
\text { week }\end{array}$ & $\begin{array}{c}\text { Average } \\
\text { energy/day, } \\
\text { W-hr }\end{array}$ \\
\hline $\begin{array}{l}\text { Earth station } \\
\begin{array}{l}\text { Telephone } \\
\text { terminal }\end{array}\end{array}$ & 360 & 8 & $6 / 7$ & 3154 \\
Graphics/FAX & 100 & 8 & $6 / 7$ & 686 \\
Audio convener & 35 & 8 & $6 / 7$ & $\underline{240}$ \\
Total & & & & 4286 \\
\hline
\end{tabular}


TABLE II. - CONTRACT TASKS

\begin{tabular}{|c|c|}
\hline Task & \multicolumn{1}{|c|}{ Description } \\
\hline 1 & $\begin{array}{c}\text { Develop design of PV power system } \\
\text { System fabrication and proof-of-design } \\
\text { testing } \\
\text { System revisions, preshipment inspection } \\
\text { and tests }\end{array}$ \\
4 & $\begin{array}{l}\text { Packaging and shipping } \\
5\end{array}$ \\
6 & $\begin{array}{l}\text { Installation, checkout and user training } \\
\text { Preparation of manuals and training materials }\end{array}$ \\
8 & System performance evaluation and operational \\
support & Interim, design, performance and final reports \\
\hline
\end{tabular}

TABLE III. - CONTROLLER FUNCTIONS

\begin{tabular}{|c|c|c|c|}
\hline \multicolumn{2}{|r|}{ Voltage increasing } & \multicolumn{2}{|r|}{ Voltage decreasing } \\
\hline $\begin{array}{l}\text { System } \\
\text { voltage, } \\
\text { V }\end{array}$ & Action taken & $\begin{array}{c}\text { System } \\
\text { voltage, } \\
V\end{array}$ & Action taken \\
\hline $\begin{array}{l}62.0 \\
60.0 \\
56.4 \\
55.0\end{array}$ & $\begin{array}{l}\text { Array and generator disconnected } \\
\text { Two-thirds of array turned off } \\
\text { One-third of array turned off } \\
\text { Generator turned off to stop battery } \\
\text { charging }\end{array}$ & $\begin{array}{l}57.0 \\
53.6 \\
46.8 \\
43.2\end{array}$ & $\begin{array}{l}\text { Two-thirds of array turned on } \\
\text { One-third of array turned on } \\
\text { Generator turned on to charge batteries } \\
\text { All loads disconnected }\end{array}$ \\
\hline
\end{tabular}




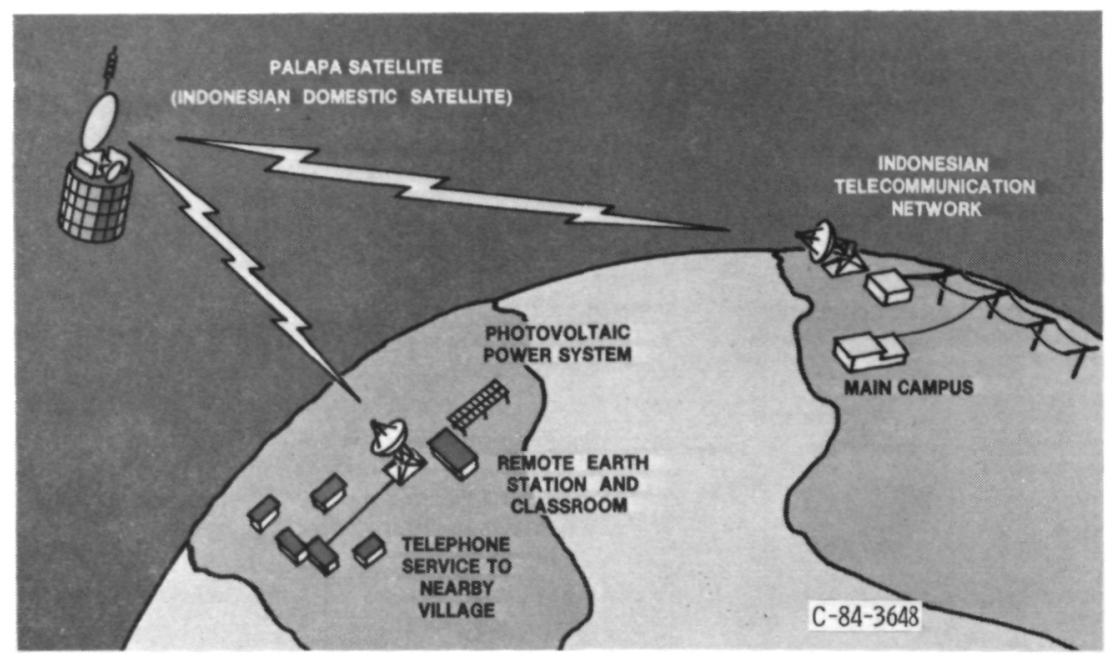

Figure 1. - Photovoltaic power system for remote telecommunication application in Indonesia.

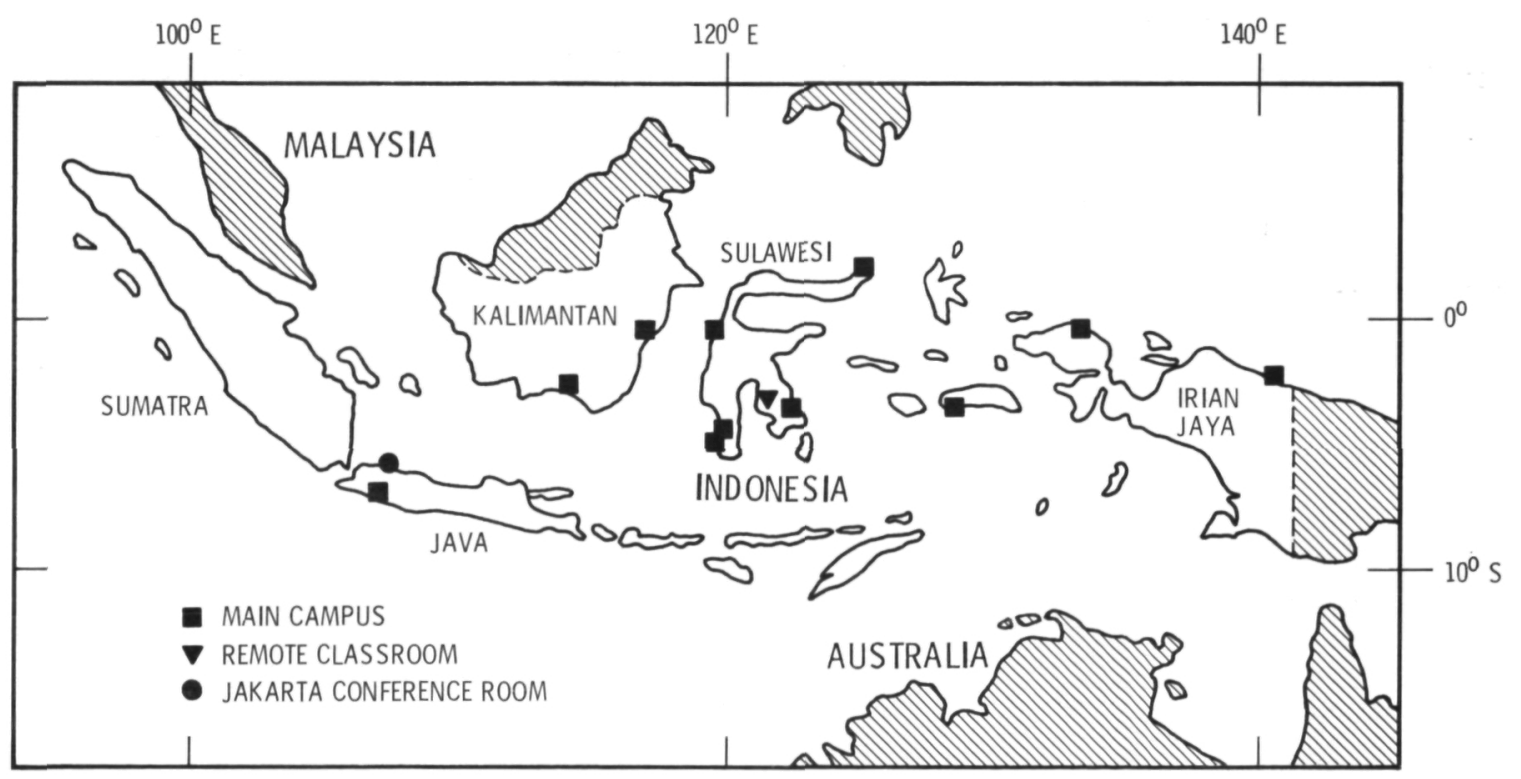

Figure 2. - Indonesian rural satellite project - site locations [1]. 


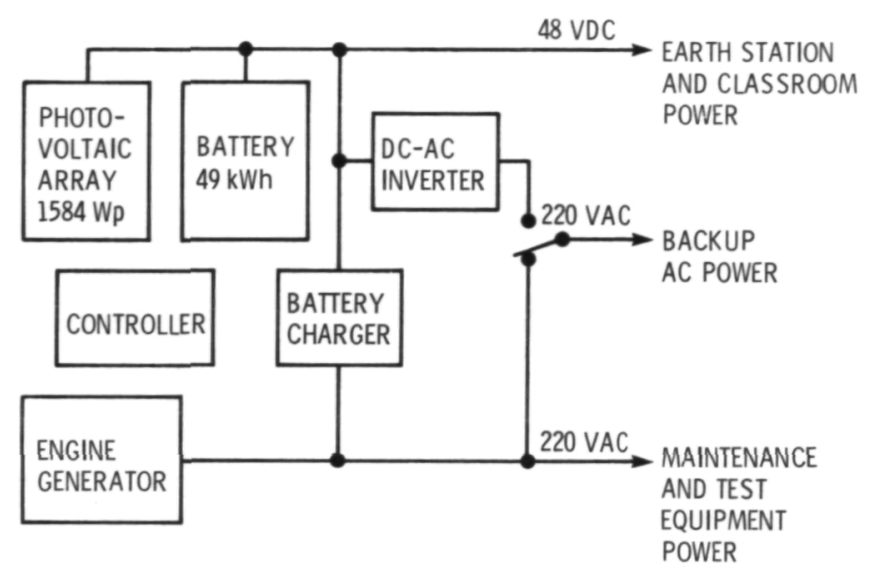

Figure 3. - PV power system block diagram

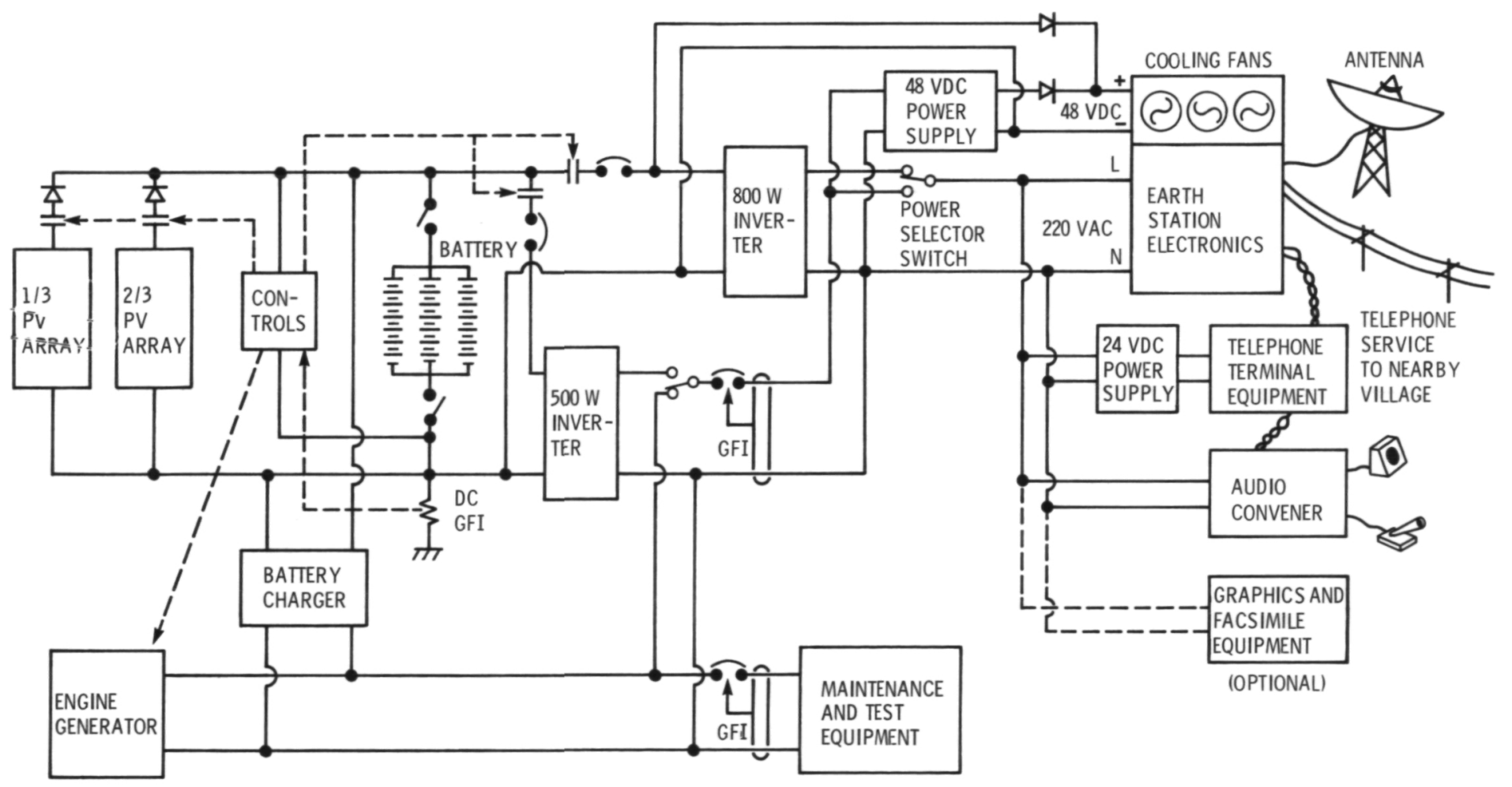

Figure 4. - PV power system, earth station and classroom equipment schematic diagram. 


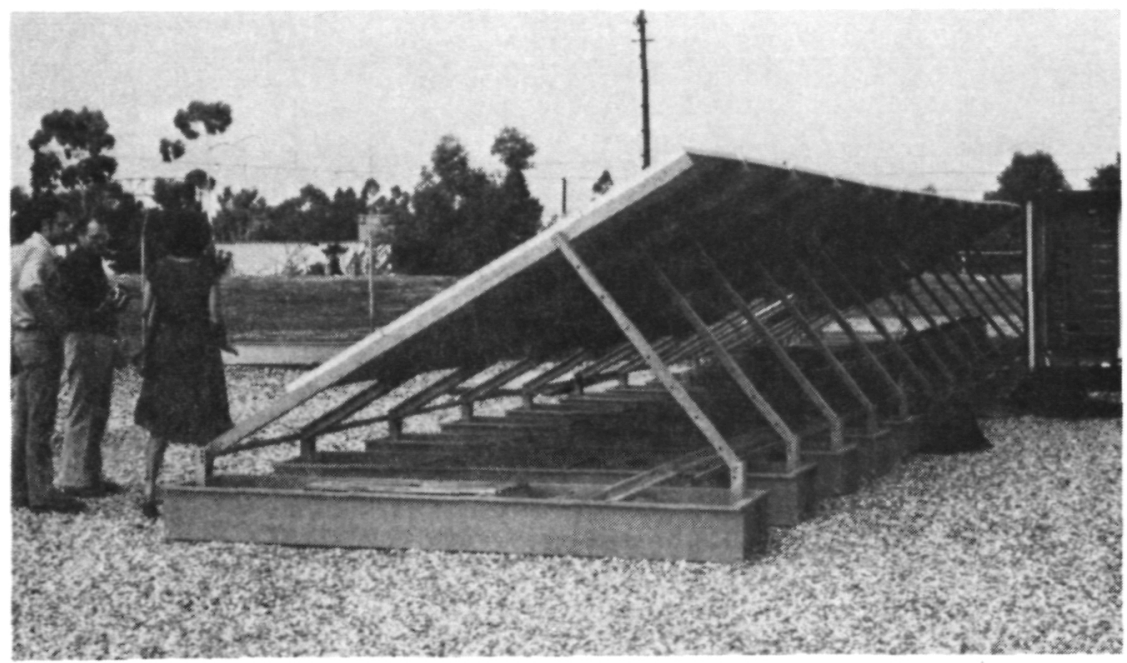

Figure 5. - Array structure.

PHOTOVOLTAIC POWER SYSTEM

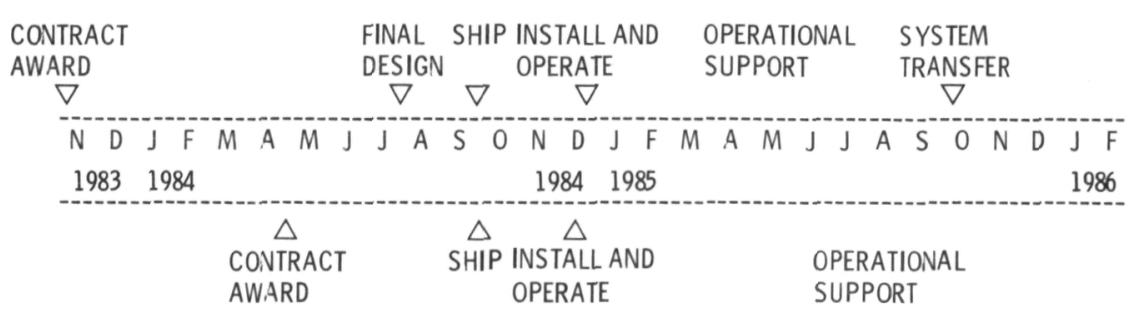

EARTH STATION

Figure 6. - Schedule and milestone chart. 


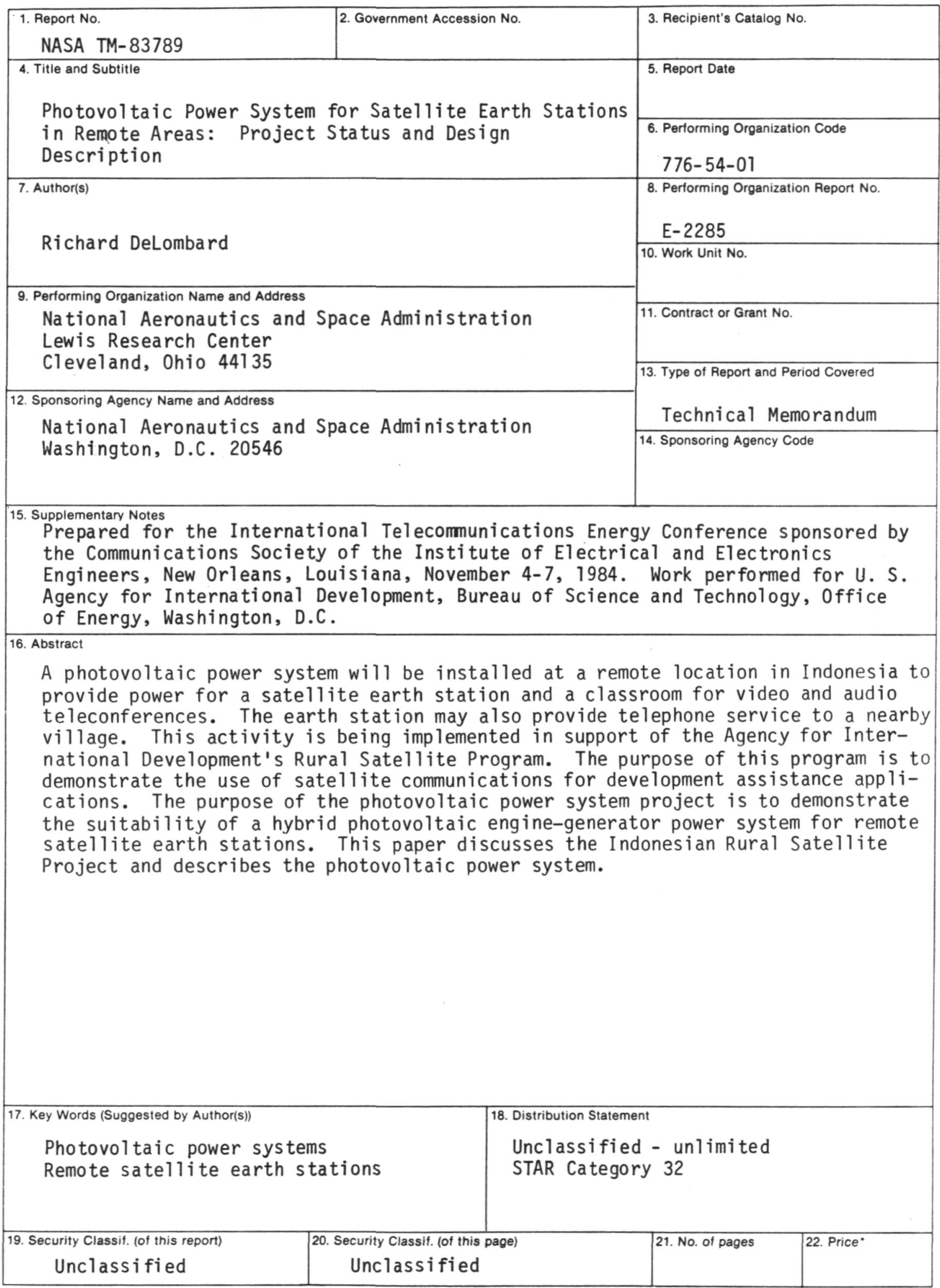

"For sale by the National Technical Information Service, Springfield, Virginia 22161 
National Aeronautics and Space Administration

Washington, D.C.

20546

Official Business

Penalty for Private Use, $\mathbf{\$ 3 0 0}$

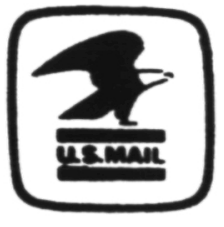

Postage and Fees Paid National Aeronautics and Spece Administration NASA-451 